\title{
The Convincing Ground Aboriginal massacre at Portland Bay, Victoria: fact or fiction?
}

\author{
Ian D Clark
}

In 2005 the so-called 'Aboriginal History wars' moved from Tasmania to a new convincing ground in Victoria. Michael Connor contested the historiography behind an alleged Aboriginal massacre at a site known as the 'Convincing Ground', at Allestree, on the coast some ten kilometres north of Portland. ${ }^{1}$ The site came to public attention in January 2005 when Aboriginal Cultural Heritage Officers halted bulldozing and development work that had begun as part of a proposed coastal residential development. ${ }^{2}$ It subsequently became the subject of a Federal Court Native Title case and a Victorian Civil Administrative Tribunal hearing. ${ }^{3}$ The dispute with the residential developer was settled in February 2007 when it was agreed that an area of land that encompasses the Convincing Ground would be set aside as a reservation. ${ }^{4}$

The purpose of this paper is to respond to Connor's critique that the massacre did not take place and that I have fabricated the story and embellished the narrative. The paper rebuts Connor's claims and others, by revisiting my earlier work on the Convincing Ground and by presenting new and important material. It examines the strategies Connor uses to claim the massacre could never have happened, and critiques his interpretation of the evidence. By identifying his key tactics and showing how he has deliberately set out to manipulate and misread the evidence, the paper deconstructs Connor's approach as a massacre denier.

\section{Connor's claims}

The Convincing Ground 'massacre' has been discussed by myself, Critchett, Connor, and Anderson. ${ }^{5}$ In a recent opinion piece, in his role as editor of Quadrant Online, Michael Connor offered the following comment on the historiography of the Convincing Ground:

Another story [in Clark's 1995 Scars in the Landscape] is based on original sources which have been misread and misused to put together a massacre

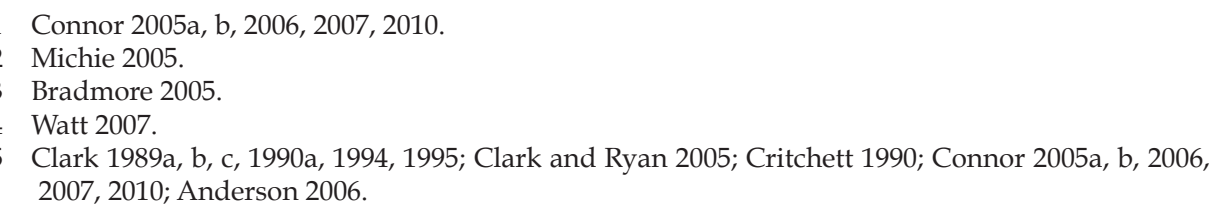


narrative. All Clark has really achieved is the ruination of modern lives and the inflaming of dissension in a small coastal community. It is the incident he places at a locality named the Convincing Ground near Portland in Victoria. Clark's story is unfounded. After a committee of the Victorian Heritage Council heard evidence, and what appeared to be 'oral history' based on Clark's history, committee member Damien Cash, the only historian who heard the case, issued this dissenting comment which accurately sums up what has happened: 'the massacre claim was revealed a case study in the misuse of historical evidence, beginning with a series of errors made by Robinson in 1841-42, and then perpetuated through a series of unreasonable conclusions and other errors made by historians'. In this particular instance Richard Broome is involved in the mess these errors have caused, and rather than acting to set the record straight, he has contributed to Clark's misuse of sources himself adding an invented death toll of sixty people. ${ }^{6}$

Connor contends here that false knowledge of the massacre has led to the 'ruination of modern lives and the inflaming of dissension in a small coastal community'. On the contrary, Connor's intervention has caused irreparable grief and harm. Connor's use of vituperative language is ultimately counterproductive to the investigation of massacre where a cool head and temperate language is critical. Semelin has argued that when '[c]onducting empirical case studies on a particular massacre', the 'facts need to be reconstructed almost as if they would in a police investigation'. ${ }^{7}$ Connor implies that historians violently disagree with the evidence. As will be shown in this article, this is a simplistic assessment that assumes that history is a one-dimensional flat terrain in which certainty can be known. Ultimately this view is counterproductive to the investigation of massacre, which is typically a difficult task as 'massacre is often carried out in secret'. ${ }^{8}$ Bain Attwood, in a public lecture in September 2005, on the release of his book Telling the Truth about Aboriginal History, raised some critical issues that take us to the heart of the debate over the Convincing Ground. He asked:

'Whose accounts should they [the public] believe? Which of the historical narrators or history-makers should they trust? Where might the truth of this history lie? There might also be other questions they are asking too: Can we learn the truth about what happened there more than 170 years ago ${ }^{\prime 9}$

\section{Convincing Ground: the context}

George Augustus Robinson, the Chief Protector of Aborigines in Port Phillip from 1838 until early 1850, learned of the Convincing Ground in May 1841 on

6 Connor 2010: 35-36.

7 Semelin 2007: 376 .

8 Semelin 2007: 376.

9 Attwood 2005b: 2. 
a visit to Portland. He considered that it was a 'remarkable' place on the coast whose name originated from severe conflict between Aborigines and Europeans. Connor observes:

On the coast outside Portland in Victoria is a locality known as Convincing Ground. Scars in the Landscape played a role in placing a massacre as the origin of the place name. In the writings of the Chief Protector of the Aborigines George Robinson, was an after-dinner story of violence which he embroidered on, and which was, almost 150 years later, much improved by Ian Clark and other historians. The story Robinson was told by a white settler only emerged late in the twentieth century when transcriptions of his papers were made. ${ }^{10}$

In this statement Connor is questioning first, the integrity of the informants; second, the situation in which the evidence was first presented, including Robinson's account; and third, my own account of the event. Let us take these issues in order. Connor questions the integrity of the people who attended the dinner and their 'after-dinner story of violence' by implying that all after dinner stories are unreliable. Connor conveniently overlooks the fact that the informants were the elite of the Portland district. Connor's view of Robinson's account is that it 'is interesting but as historical evidence it lacks clarity. Where it took place and how many people were involved is not clear. When it took place was not specified. Who, if anyone was injured is not suggested' ${ }^{11}$ He continues:

Neither Blair nor Tyers had long been in Portland. Both men were offering suggestions for the origin of the place name. Here, it is important to note, Blair did not say that the fight over the whale was the basis of the place name but 'some transactions with the natives of the kind mentioned'. ${ }^{12}$

Connor claims that Robinson's 'story' only emerged late in the twentieth century, but on this point he is wrong as a survey of the publication of Robinson's material clearly shows. ${ }^{13}$ Connor is using the tactic of deflection here, also known as 'furphies' or 'red herrings', to divert the reader away from considering critically important aspects of Robinson's evidence. Connor claims the incident did not become known until Robinson's journals were published in the late twentieth century. Robinson's references to the Convincing Ground were in his private journals for 1841 and 1842 and in an official report of his 1841 journey that he submitted to government in late 1842. The 1841 journal entries have been transcribed and published by Presland, and Clark, and the 1842 journal entries have been published by Clark. ${ }^{14}$ Parts of Robinson's official report were published by Kenyon, and Learmonth, and the complete report has since been

10 Connor 2005a: 140

11 Connor 2005a: 142.

12 Connor 2005a: 142.

13 Similar claims were made by Keith Windschuttle in his arguments against the Cape Grim massacre in Tasmania: see McFarlane 2008: 128.

14 Presland 1980; Clark 1988, 1998, 2000a. 
published by Clark. ${ }^{15}$ Kenyon published an abridged version of the official report in 1928, and although he omitted as much as 50 per cent of its content, he did reproduce Robinson's discussion of the Convincing Ground. This would suggest that Kenyon is the first known published report of the incident. Thus Connor's assertion that the 'story Robinson was told by a white settler only emerged late in the twentieth century when transcriptions of his papers were made' is clearly incorrect.

\section{Origin of name ‘Convincing Ground'}

A second example of deflection used by Connor is to focus on the dispute surrounding the origin of the name 'Convincing Ground'. He implies that if the name did not exist at the time of the incident, or that it had another meaning, then the massacre could not have taken place. Analysis will show that denying the name does not deny the massacre. There are at least four explanations of the origin and meaning of the place name 'Convincing Ground' found in primary and secondary literature relating to south-west Victoria. The first explanation involves Aboriginal people and whalers in disputation and has two variants: one found in Robinson's writings from 1841 and 1842 is that the dispute was over a beached whale; the other, presented by Critchett, is that the dispute was over whalers' abuse of Aboriginal women. ${ }^{16}$ The second explanation, which Robinson sourced from CJ Tyers in 1841, is that the name originated from whalers choosing that site to settle their disputes. It was repeated by Dunderdale and by Moorhouse. ${ }^{17}$ A third explanation promoted by local historian JG Wiltshire in 1976 is that it originated from Major Thomas Mitchell's visit to Portland Bay during his 1836 'Australia Felix' expedition. Local historian JM MacKenzie has suggested a fourth explanation that it was a 'whalers term for his outdoor factory' where whale oil was 'tryed out of the blubber', but no other authority has supported this explanation. ${ }^{18}$

\section{Dispute between Aborigines and whalers over a beached whale}

George Augustus Robinson is the sole source of this explanation, based on information given to him by Edward Henty and James Blair in 1841 during a visit to Portland when he was touring the Western District of the Port Phillip Aboriginal Protectorate. Robinson was given two explanations, however he

15 Kenyon 1928; Learmonth 1934; Clark 1990b, 2001.

16 Critchett 1990.

17 Dunderdale 1973[1870]; Moorhouse 1888.

18 MacKenzie 1976: 25. Geoff Parker, in an unpublished manuscript dated 24 November 2005, has advanced the following view that in 1833 Edward Henty and Captain Liddle of the Henty owned vessel the Thistle, when on a visit to Portland Bay 'dug a turf from a hill overlooking the beach and carried it back to Launceston to help convince Thomas [Henty] that Portland Bay was the end of the Hentys' long quest' for land suitable for pastoral development. Thus, the 'place were the black clod of earth was removed is Edward Henty's "convincing ground"'. No other source has supported this interpretation of the origin of the place name. 
believed that the explanation involving a clash over a disputed whale was the most feasible. Robinson visited Portland in May 1841, and on 16 May during a meal he shared with Charles Tyers, Daniel Primrose, Edward Henty, and James Blair, he learned the origin of the name Convincing Ground. ${ }^{19}$ He related in his journal:

Mr Edward Henty and Mr Blair called and spent the afternoon. We had tea and coffee, wines and dessert after dinner. Mr Henty said the Blacks at Mt Clay are a bad set and he did not think I should get a communication with them. I said I did not lay wagers but I could venture to do so in this case; that I should get to them. He related one story of their badness. He said that some time ago, I suppose two or three years, a whale broke from her moorings and went on shore. And the boats ${ }^{20}$ went in to get it off, when they were attack by the natives who drove them off. He said the men were so enraged that they went to the head station ${ }^{21}$ for their firearms and then returned to the whale, when the natives again attack them. And the whalers then let fly, to use his expression, right and left upon the natives. He said the natives did not go away but got behind trees and threw spears and stones. They, however, did not much molest them after that.

There is a spot on the north shore, where the try ${ }^{22}$ works are I think, which is called the 'Convincing Ground' and I was informed that it got its name from some transactions ${ }^{23}$ with the natives of the kind mentioned, so $\mathrm{Mr}$ Blair said. Mr Tyers however said it was because when the whalers ${ }^{24}$ had any disputes they went on shore and there settled it by fighting. I however think the former the most feasibly, especially after what $\mathrm{Mr}$ Henty himself stated..$^{25}$

19 Surveyor Charles Tyers arrived at Portland on 14 November 1840; Daniel Primrose was described by Robinson as clerk of the bench, sub-collector of customs and postmaster; and Edward Henty arrived at Portland on 19 November 1834. James Blair was appointed Magistrate at Portland Bay in 1840 and arrived at the Bay in October 1840 (Bride 1983: 176).

20 Connor mistranscribes this as 'boat' - it is most certainly 'boats'. Peel (1996: 24), in a discussion of whaling at Portland, has noted that a 'whaling party conventionally consisted of three boats, or four where the competition was strong'. She notes that whale boats were usually manned by five oarsmen and a headsman except when competition increased when a boat with seven or more oarsmen might be used.

21 Connor (2007: 1) comments 'the word "station" is incorrect. Robinson's writing is unclear and I suggest the word may be "flenser", so that the men went to the "head flenser" for arms. If this reading is correct, it suggests that in this whaling station guns were secured by a responsible person. It also suggests that Henty had reasonably detailed knowledge of the event'. Connor's reading is incorrect: the word is clearly 'station' - the letter he takes to be 's' is most certainly the consonant ' $t$ '. It has the $t$ cross bar that is not found in the consonant ' $s$ '.

22 Connor (2007: 1) correctly transcribed this as 'try'; earlier transcriptions by Presland (1980) and Clark (1998, 2000a) had 'big'.

23 The manuscript reads 'transactions'. This is the only time the particle ' $s$ ' is used; in all later discussions Robinson uses the singular.

24 Connor correctly transcribed this as 'whalers'; it was mistranscribed as 'whites' by Presland (1980) and Clark (1998, 2000a).

25 Robinson, Journal 16 May 1841. 
The following day, Robinson added further details to his journal:

[Blank] miles from Double Corner is Messrs Hentys' fishery. This spot where the buildings are is called the Convincing Ground, see note for Sunday and Monday. It is stated that the natives fought the whalers. Now, the cause of this fight, if such an unequal contest can be so designated, firearms [are] certain death against spears, was occasioned by the whalers going to get the whalebone ${ }^{26}$ from the fish, when the natives, not knowing their intentions and supposing they intended to take away the fish which the natives considered theirs and which it had been for 1000 of years previous, they of course resisted the aggression on the part of the white men. ${ }^{27}$ It was the first year of the fishery, ${ }^{28}$ and the whalers having used their guns beat them off and hence called the spot the Convincing Ground. That was because they convinced them of their mistake and which, but for their firearms, they perhaps could not have done. $^{29}$

Connor's commentary on this entry is that:

Robinson has expanded on the whale incident. He offered no sources for the new information or suppositions he was adding to the original story. ... The original 'aggression' in Henty's story had been on the part of the Aborigines, Robinson now transferred that to the whalers. If the Aborigines in Henty's story were from the local area, though they may not have been, they would have known that the whalers were only after part of the whale. 'It was the first year of the fishery' may be an invention on the part of Robinson and is little help in dating the incident for it is uncertain what fishery he was referring to. ${ }^{30}$

Connor reveals here that he is an eisegete, in that he dismisses or ignores parts of the evidence that do not suit his argument. Connor assumes that the Aboriginal people would have known that all they had to do was wait till the whalers had finished with the beached whale and it would have been theirs without interruption (a la Mitchell's 1836 account of the sagacity of the Aborigines in waiting for discarded whale carcass). Yet, that assumes that the Aborigines had previously seen whalers flensing beached whale, and this might well be the

26 Whalebone is also known as baleen.

27 See Clarke 2001. Mark Staniforth (2008: 126) has commented that 'Groups of Indigenous people in Australia had utilised beached (or stranded) whales as a food source long before permanent European settlement in 1788 and whale strandings were occasions for feasting'. Especially, since whale meat was a rich source of protein for Aboriginal groups (Staniforth 2008: 130). Anderson (2006: 137) has noted that archaeological evidence in the Portland area demonstrates Aboriginal use of coastal areas and occupation for at least 12,000 years.

28 Edward Henty landed in Portland Bay on 19 November 1834 (Learmonth 1970: 3). William Dutton settled permanently in Portland Bay in 1828, and settled at Double Corner in 1829. Presland (1980) mistranscribed this sentence as 'It was the first guns of the fishery'. This subsequently misled research by Critchett (1990) and Clark (1995). The sentence was transcribed correctly by Clark (1998, 2000a).

29 Robinson, Journal 17 May 1841 in Clark 2000a: 208.

30 Connor 2005a: 145. 
point of the Convincing Ground incident: that because it occurred in the first year of the fishery it might have involved the first clash over a beached whale that had been harpooned. Hence the importance for the whalers of making a stand and convincing the Aborigines that they no longer had free access to beached whales. Connor's comment that Robinson might have invented the sentence about it being the first year of the fishery is implausible, and so can be dismissed as empty eisegesis. Connor contests the integrity of Robinson as a source of information, yet he was the most experienced massacre investigator in Australia at the time. He had investigated massacres of Aboriginal people in Tasmania in the early 1830s and his accumulated knowledge of how massacres happened had given him great insights into their investigation.

In his official report of his 1841 journey into western Victoria, Robinson discussed the incident in the following terms:

Among the remarkable places on the coast, is the 'Convincing Ground', originating in a severe conflict which took place a few years previous between the Aborigines and Whalers on which occasion a large number of the former were slain. The circumstances are that a whale had come on shore and the Natives who feed on the carcase claimed it was their own. The whalers said they would 'convince them' and had recourse to firearms. On this spot a fishery is now established. ${ }^{31}$

Major TL Mitchell and his exploration party arrived in Portland Bay in August 1836, and although Mitchell's journal does not specifically mention the Convincing Ground as either a place or an incident, on 30 August 1836 he does discuss interactions between whalers and Aboriginal people that are very reminiscent of the account told to Robinson in 1841:

I understood it frequently happened, that several parties of fishermen, left by different whaling vessels, would engage in the pursuit of the same whale, and that in the struggle for possession, the whale would occasionally escape from them all and run ashore, in which case it is of little value to whalers, as the removal, \&c, would be too tedious, and they in such cases carry away part of the head matter only. The natives never approach these whales, nor had they ever shewn themselves to the white people of Portland Bay; but as they have taken to eat the cast-away whales, it is their custom to send up a column of smoke when a whale appears in the bay, and the fishers understand the signal. This affords an instance of the sagacity of the natives, for they must have reflected, that by thus giving timely notice, a greater number will become competitors for the whale, and that consequently there will be a better chance of the whale running ashore, in which case a share must fall finally to them.

31 Clark 1990b: 108; 2001: 21. 
The fishers whom I saw were fine able fellows; and with their large ships and courageous struggles with the whales, they must seem terrible men of the sea to the natives. ${ }^{32}$

An entry in Francis Henty's journal for this period notes that he rode with brother Edward and Mitchell 'to the convincing ground with him [ie Mitchell] when we parted'. ${ }^{33}$ This could well explain the similarity between Mitchell's narrative and the later one given to Robinson - they both derive from Henty. Another observation to make on Mitchell's comment is that the reluctance of Aboriginal people in 1836 to approach beached whales that had escaped from whaling crews along with their contentment with eating cast-away whales is consistent with them having been taught a lesson that they were not to try to take beached whale but to wait their turn. Thus it is plausible that the Convincing Ground incident had already occurred and that Mitchell was describing the post-incident reality. ${ }^{34}$

Aboriginal harvesting of beached whale is supported by local squatter Thomas Browne, who argues that the Aboriginal people on and near the south-western coast of Victoria

'had been for untold generations accustomed to a dietary scale of exceptional liberality. The climate was temperate; the forests abounded in game; wild fowl at certain seasons were plentiful; while the sea supplied them with fish of all sorts and sizes, from a whale (stranded) to a whitebait' ${ }^{\prime 35}$

It is also confirmed by an article in the Portland Guardian of 13 July 1844 . The newspaper reported that Aborigines were attracted to 'putrid carcasses of 2 or 3 whales near double corner after regaling themselves on the savory morsel which drew them from their ordinary haunts and employment to Portland... Portland residents had not for two years witnessed such a large gallery of Aborigines and many visited their encampment and were confounded to see them profess to cook, and actually devour the filth which the whale carcass of the time rapidly decomposing, afforded them'.

When Robinson camped at Double Corner on 14 May 1841, 'from the general report of the settlers I was induced to suppose that the majority of the natives would be congregated at Portland Bay as the whaling season had commenced, and they would go there in quest of cun.der.bul, whales'. Robinson considered the congregation of large numbers at Portland Bay would be opportune for

32 Mitchell 1996: 242-243.

33 Peel 1996: 163.

34 Of course another observation is that Mitchell's account lacks substance. Parker (2005) has suggested that the known practice of shore-based whaling - that of deliberately beaching whales for processing by tonguers - contradicts Mitchell's account. However, Parker's qualification is only sound if the whales are beached reasonably close to the try-works as any distance would make it difficult to carry strips of blubber to the nearest rendering plant. Mann (1839: 242) refers to the practice at Portland: 'A few years ago they had seventeen whales killed and dragged ashore at one time'.

35 Boldrewood 1969: 40. Browne was at Squattleseamere station on the Eumeralla River south of Macarthur from 1844 until 1862. 
he could procure supplies more easily for a large party at the bay than if they were inland as he would have to cart them at much expense. However, once in Portland, he learned from Edward Henty that 'the blacks had not visited the settlement at the bay for some years and the blacks at Mt Clay and between the first and second rivers are a wild set and will not allow white persons to come to them' ${ }^{36}$ At his first meeting with Blair, the police magistrate, Robinson noted: 'Mr Blair has had no communication with the natives and only knows what has been told him'. ${ }^{37}$ Further on he noted: 'There have been no natives seen at Portland for the [blank] years. Indeed, they never visit the town and the Mount Clay natives will not allow any person to go near them' ${ }^{38}$ Again, this avoidance of Portland by the Mt Clay people supports the contention that things were not right at Portland.

Connor is of the view that a 'serious contemporary argument against the massacre story is the behaviour of the Aborigines' during Robinson's visit to the Portland district in May 1841. He claims that: 'Travelling to a camp closer to Double Corner they showed absolutely no fear of crossing the Convincing Ground site, or of the whalers' ${ }^{39}$ In fact Robinson and his attendants had a difficult time in keeping the Aborigines and the whalers apart. ${ }^{40}$ The young whalers they encountered, both at the Convincing Ground and in the bush, tried hard to attract the attention of the Aboriginal women. This is Connor's third example of deflection. He is arguing that the massacre could never have happened because the Aboriginal people did not avoid the Convincing Ground during Robinson's visit in May 1841. Connor reveals his superficial understanding of the operation of the Port Phillip Aboriginal Protectorate, in that he does not understand Robinson's modus operandi when he travelled in the early years of the protectorate with the intention of meeting Aboriginal people. Nor does he comprehend the affection and respect that Aboriginal groups conferred on Robinson. They were as keen to meet with him as he was with them. The reason for their willingness to travel to Double Corner was to meet with Robinson and to receive the gifts and food they were promised, as can be seen in the description above. Robinson left Melbourne with two European assistants who were attached to the protectorate's central office in Melbourne, and Pevay, one of several Aboriginal Tasmanians in Robinson's care. As they travelled through the Western District, Robinson recruited local Aboriginal people to travel with him as guides and envoys, and as facilitators of meetings with other Aboriginal people. When he arrived at Portland, Robinson was accompanied by a large entourage of Aboriginal people..$^{41}$ Robinson travelled with as much fanfare as he could orchestrate; he wanted to impress upon the Aboriginal people of western Victoria that he was their Chief Protector, and that

36 Robinson, Journal 15 May 1841 in Clark 2000a: 202.

37 Robinson, Journal 15 May 1841 in Clark 2000a: 202.

38 Robinson, Journal 16 May 1841 in Clark 2000a: 206.

39 Connor 2007: 2.

40 Connor is obfuscating here, another well-known tactic of massacre deniers. In fact, Robinson had trouble keeping the whalers from the Aborigines, not vice versa. Connor is seeking to subvert the historical context.

41 See Robinson, Journal 28 May 1841 in Clark 2000a: 226. 
he had many gifts and supplies to distribute. He also wished to gather as much intelligence about them as he could about their language, social groupings, customs, demography, and so forth.

Robinson's visit was a significant event - significant enough that it saw the Kart gundidj and other clan remnants living with them willingly break their apparent prohibition against visiting Portland. Thus, Robinson's visit to Portland and his meeting with the local Aboriginal people represented a fundamental repositioning of their relationship with local Europeans as their apparent avoidance of Portland appears to have ended with Robinson's visit. This was confirmed with striking effect on 2 June 1841, less than a fortnight after Robinson had left Portland to continue his tour of the Western District of the Aboriginal protectorate. On that day, Police Magistrate James Blair sent a letter to Superintendent La Trobe:

A messenger has just arrived from the Convincing Ground with the intelligence that upwards of 200 Blacks have assembled there \& the whalers are in consequence obliged to remain on shore, being in momentary expec- of an attack on their huts. ${ }^{42}$

\section{The dispute with whalers was over Aboriginal women}

Jan Critchett has argued that there is another explanation of the conflict between whalers and Aboriginal people: that on 23 March 1842, MacDonald, the headsman at Captain Alexander Campbell's station on the Merri River near Port Fairy told Robinson 'some whalers had got among or with the N- [Native] women', and that this was the cause of the Convincing Ground dispute. ${ }^{43}$ However not only has Critchett mistranscribed Robinson's journal entry, she has misunderstood its context. Robinson's entry is as follows:

It was 8 or 9 years ago the collision between the whalers \& blacks took place at the Convincing Ground. MacDonald, the headman, said some got among or with the native women. ${ }^{44}$

On this day Robinson met with 30 Aboriginal men and women from seven Dhauwurdwurrung clans. Presumably these people discussed the Convincing Ground massacre or it was raised by MacDonald or Campbell. With the correct transcription, MacDonald may not be claiming a different cause of the Convincing Ground massacre, but simply stating that some of the whalers were having sex with Aboriginal women. The greatest flaw with Critchett's argument is that when Robinson came to finalise and submit his official report of his

42 Blair 2 June 1841 in VPRS 10. This was not the only time conflict ensued after Robinson had visited a locality and met with local Aboriginal people. James Kirby (1895: 52) at Piangil on the Murray River near Swan Hill considered Robinson's visit to the station in 1846 was the cause of conflict that ensued between Aboriginal people and the Beveridge family.

43 Critchett 1990.

44 Robinson, Journal 23 March 1842 in Clark 2000a, 2: 48. 
1841 journey, which he completed and submitted after his March 1842 sortie to Port Fairy, he did not change his description of the Convincing Ground: the narrative continued to be around conflict over a beached whale, not over access to Aboriginal women. Robinson was never afraid to comment on and be critical of the sexual exploitation of Aboriginal women, so it is unlikely that he would be coy here. Thus the two sentences are not connected and the cause of the dispute remains contested ownership of a beached whale.

Connor makes much of the 1842 report: 'Robinson's last reference to the Convincing Ground appears in his official report which was not written until October 1842 - some 17 months after he had visited Portland' ${ }^{45} \mathrm{He}$ is critical that the 'text has sometimes been given out of chronological order by historians' and in his article and chapter he places it in the correct order. Connor makes much of this chronology, but ultimately it is a deflection that when examined in greater detail does more harm than good to Connor's case. That the official report was in all likelihood finalised after Robinson's 1842 visit to the Port Fairy district strengthens the Convincing Ground case and weakens Connor's argument dramatically. The report was submitted to government on 7 October 1842, the date of its accession. Robinson returned to Melbourne from his five month Western District expedition in August 1841 and promised La Trobe 'a full report of my proceedings I shall do myself the honour to transmit for the information of the Government'. ${ }^{46}$ Robinson took 14 months to submit the report. We cannot be certain when the final report was written, but if we accept that it was written after Robinson's March 1842 Port Fairy visit, then the consistency between Robinson's official report and his 1841 journal entries confirms that Critchett's and Connor's arguments that there is another explanation for the conflict between the whalers and Aborigines have little credibility.

Another problem with the two sentences in Robinson's 23 March 1842 journal entry is that they may not be related to one another. Connor observes that in my 1995 publication I seem to be:

separating the two sentences so that the first is taken to be a reference to the fight over the whale and the second no more than an irrelevant general comment about whalers and women. When Clark told the story in Scars in the Landscape, he did not print the two sentences or even mention MacDonald. ${ }^{47}$

Connor is correct: this was a deliberate separation. In Robinson's journal his narrative for that particular day is interrupted by two pages of jottings. On the first page was the sentence that: 'It was 8 or 9 years ago the collision between the whalers \& blacks took place at the Convincing Ground'; and on the second page, the sentence: 'MacDonald, the headman, said some got among or with the native women'. While Connor quite rightly went to the primary source and

45 Connor 2007: 3.

46 Robinson, VPRS 10 Item 41/1207 in Clark 1990b: 99.

47 Connor 2005a: 149. 
consulted Robinson's 1841 manuscript, he should also have gone to Robinson's 1842 manuscript where he would have seen that they are not in all likelihood connected, and this would have made sense of the Convincing Ground entry in my 1995 publication. Nevertheless, even if they are related, the argument that MacDonald is proffering a new explanation for the Convincing Ground incident is flawed.

\section{A place where whalers settled their own disputes}

When Robinson was told about the Convincing Ground place name he was given a second explanation by surveyor CJ Tyers. He said that the name emerged because 'when the whalers had any disputes they went on shore and there settled it by fighting'. ${ }^{8}$ Surveyor Tyers had been in the Portland district since November 1840. Of the two explanations given to him, Robinson considered Blair's explanation relating to a contest over a beached whale to be the more feasible, especially after what Henty had told him.

There are two nineteenth-century published references to the Convincing Ground. The first from George Dunderdale gave the following explanation of the name: 'the Convincing Ground, which was so-called because the whalers used to go down there to fight, and convince one another who was the best man'. ${ }^{49}$ The second reference is found in a March 1888 address entitled 'Victoria' given by Dr James Moorhouse, the Right Rev the Lord Bishop of Manchester, which he delivered to members of the Manchester Geographical Society, and subsequently published in the Society's journal: ${ }^{50}$

At last, however, two gentlemen called Henty went from Tasmania and landed at Portland. They set up an establishment, which was partly a grazing establishment and partly a fishing establishment. They catch whales there, which is, perhaps, something you did not know. This was one of the employments of the persons engaged by these Hentys. I may tell you, in passing, that it was difficult to keep order in those early days. The people were not lawless, but they were rough. And when the partners got any persons to enter their service they were apt to affirm their own independence and there was no way of reducing them to subjection and of keeping order in the little settlement but by appointing one of the partners to [be] the representative of physical force. There was a certain field, which was called the "Convincing Ground", and if any man thought he was a better man than the master, Mr Henty would say "Come to the Convincing Ground". Thither they would go, take off their

48 Robinson, Journal 16 May 1841.

49 Dunderdale 1973[1870]: 40.

50 Connor makes no reference to this source. 
coats, and try who was the better man of the two. For the most part Mr Henty thrashed his man, but if a man thrashed Mr Henty he was dismissed..$^{51}$

This is an extraordinary discussion in that it places the Henty brothers as central participants in the explanation of the Convincing Ground as a site where intrawhaler disputes were settled. Indeed, Moorhouse is not stating that this is a place where whalers per se settled their disputes, but where the Henty brothers settled their disputes with their employees, who may or may not have been whalers. Thus it was a site where employer-employee disputes were resolved. Moorhouse came to Victoria where he was installed in early 1877 as the second Anglican Bishop of Melbourne, and left Victoria in March 1886 to become the Bishop of Manchester. ${ }^{52}$ How could Moorhouse have known this intimate detail? Who was his source? Did he visit Portland during his bishopric? We learn from Moorhouse's biography that each year he would set out on visitation tours that would last several months at a time. ${ }^{53}$ However Sturrock, in her recent discussion of Moorhouse in the field, implied that he concentrated his visits on Gippsland, north-east Victoria, and the goldfields, and does not give any indication that he visited the Portland district. ${ }^{54}$ We know from Edward Henty's obituary ${ }^{55}$ that the Hentys were Anglican. Indeed, Sturrock confirms that the Henty family in Melbourne were actively involved at St Stephen's Richmond, ${ }^{56}$ so we can assert with some certainty that Moorhouse knew the Hentys personally. What do we make of Moorhouse's statement? Presumably it came from either Edward or Frank Henty or one of their children. Is it perhaps the boasting of an old man in his later years overstating his physical prowess during the early years of Portland's settlement trying to impress his listener with a crude system of employer-employee dispute resolution? Does it tell us anything about the origin of the place name or does it simply provide us with a variant description of the use of the site by the Hentys?

Connor argues that Robinson got it wrong, and considers that of the accounts given to Robinson, those of Blair and Tyers:

Tyers's suggestion was possibly more feasible, for 'convincing ground' was a phrase with definite and known meanings in the nineteenth century. In the Australian National Dictionary a convincing ground is defined as a place where prize or grudge fights were held. Illustrating usage, the dictionary gave examples ranging from an 1830 Sydney newspaper to a 1951 Australian novel. In 1898 George Dunderdale, in The Book of the Bush, wrote that Portland's Convincing Ground 'was socalled because the whalers used to go down there to fight, and convince one another who was the best man'. Dunderdale would not have read

51 Moorhouse 1888: 40.

52 Badger 1974.

53 Rickards 1920: 104; Serle 1949.

54 Sturrock 2005.

55 The Argus, 15 August 1887.

56 Sturrock 2005: 17. 
Robinson's journal and would not have known that this was the origin for the place name suggested much earlier by Tyers - he may only have been repeating what everyone in the nineteenth century took for granted..$^{57}$

Connor is citing from the second edition of Dunderdale's work, and has not indicated that it was first published in 1870 by Ward, Lock \& Co, of London. He also fails to mention that Dunderdale arrived in Victoria in 1853 and never lived in the Portland district. When he arrived in Victoria, he joined the central goldfields, and within four years had settled at Colac where he commenced his first appointment in the government service. In 1869 he left western Victoria for public service in south Gippsland, from where he published The Book of the Bush. He published very detailed accounts of early colonial life in Victoria, some of it of events that took place before he arrived in the colony. How could he know this detail? How did he come across these 'truthful sketches'? Walsh and Hooton consider Dunderdale's stories and sketches 'consist of historical narratives or fictional reconstructions of Australian history, dealing with the more colourful aspects of topics such as discovery and exploration, pioneering in Gippsland, convicts, shipwrecks, whaling, sealers and swagmen'.58 It is possible that Dunderdale knew Tyers and received information directly from him, ${ }^{59}$ so Tyers may be the source of the Convincing Ground gloss that he presents. Connor seems to put aside the textual criticism he applies to Robinson and his informant Blair and then fails to apply it to Dunderdale. As a result, he blindly accepts Dunderdale's explanation of the convincing ground because Dunderdale was 'repeating what everyone in the nineteenth century took for granted'. Once again, Connor is being misleading and selective of nineteenth-century references to convincing grounds. It is possible that Tyers and Dunderdale were simply guessing the origin of the Convincing Ground place name by applying their understanding of its use in other contexts in Australia.

Connor makes the following comment on the validity of Tyers' gloss on the toponym: 'Tyers suggested it was a place where the whalers went to settle their disputes. This is a completely feasible suggestion. Convincing Ground was a common term for such a place and has been used in this sense in other parts of Australia' ${ }^{60}$ A search of nineteenth- and early twentieth-century Australian newspapers and publications confirms that 'convincing ground' was indeed a term in common use. However, its application is not as simple or as exclusive as suggested by Connor. A brief sortie through the literature confirms that the use of the term 'convincing ground' is not confined to the definition given by Partridge and Beale as 'The site for a grudge fight' ${ }^{61}$ Its use in early Sydney was as the place where convicts were hanged, ${ }^{62}$ and in Brisbane in 1830 it referred

57 Connor 2005a: 142.

58 Walsh and Hooton 1998: 70.

59 Dunderdale 1973[1870]: 265.

60 Connor 2007: 1.

61 Partridge and Beale 2002: 250.

62 Anonymous 2004: 21. 
to a place of punishment of prisoners, ${ }^{63}$ of convincing those being punished of the error of their ways. It is often used to refer to the space or ground or arena where a contest is settled, hence its common usage to refer to sporting contests such as pigeon shooting at Green Ponds in Tasmania, ${ }^{64}$ horse racing ${ }^{65}$ skiff racing, ${ }^{66}$ a ploughing competition in Longford, Tasmania, ${ }^{67}$ boxing matches ${ }^{68}$ trials at agricultural shows, ${ }^{69}$ shooting matches at Ballarat, ${ }^{70}$ as well as the polling booth for a parliamentary byelection in Brisbane. ${ }^{71}$ Edmund Finn described a Grand Stand serving as a convincing ground for a contortion contest known as 'collar grinning', that was held on the first public race day in Victoria on 6 March 1838 on Batman's Hill. ${ }^{72}$ The venue for Melbourne's first duel between Peter Snodgrass and William Ryrie in 1840, 'a grassy common on the verge of the swamp northwardly adjoining Batman's Hill', was also referred to as 'the convincing ground'. ${ }^{73}$

In these examples the use of the term 'convincing ground' implies overcoming, vanquishing, and winning a contest, whether it be a sporting contest or a political contest. This understanding is consistent with Blair's explanation that the place name 'Convincing Ground' near Portland owes its origin to a dispute between whalers and Aborigines over a beached whale. The whalers named it Convincing Ground because it was where they had overcome and vanquished their Aboriginal opponents in the contest over a beached whale and they had shown the Aborigines the error of their ways. This is what toponymists refer to as an 'incident name' commemorating an event. ${ }^{74}$ But equally, its use in contemporary literature is consistent with Tyers' explanation that it originated with whalers settling their disputes by fighting. Thus both explanations have credibility when compared with other vernacular uses of the term 'convincing ground'.

One of the curious things about Tyers' explanation is the fact that other than the Dunderdale reference and the address by Bishop Moorhouse, it is not possible to find any other contemporary reference to the Convincing Ground near Portland as a place where whalers settled their disputes. Henty's writings, for example,

63 Evans 2007: 40.

64 Hobarton Mercury, 12 July 1854.

65 The Courier, 12 April 1844; Sydney Morning Herald, 17 May 1849; The Argus, 31 October 1855; Wheelwright 1861: 237.

66 Sydney Morning Herald, 21 December 1865.

67 The Mercury, 8 October 1861.

68 The Argus, 5 January 1909.

69 The Argus, 1 December 1871.

70 The Argus, 15 July 1862.

71 The Courier, 17 December 1862.

72 aka Garryowen 1888: 713.

73 Garryowen 1888: 777. It is also possible to find another instance of 'convincing ground' surviving in a local place name. In New South Wales there is a Convincing Ground Road at Karangi near Coffs Harbour. According to GE England (n.d.) the history of this place name is as follows: 'In the village at the Beacon Mines the 400 inhabitants appointed a committee to keep order in the little community. All arguments had to be settled on Sunday morning at 10 o'clock on a cleared space called the Convincing Ground'.

74 Hodges 2007: 398. 
do not discuss whalers going to the Convincing Ground to settle disputes, which is striking given Moorhouse has situated the Hentys as central to the Convincing Ground narrative. This must weaken the claim that its origin stems from a series of convincing events in which whalers went to this place to settle their grievances.

There are two toponymic possibilities not considered by Connor. The first is that the toponym 'convincing ground' may be polysemic in its vernacular usage in nineteenth and early twentieth century Australasia, that is, that it is a toponym with multiple, related meanings, as seen in the variant meanings chronicled above. The second is that the 'convincing ground' toponym at Allestree may be an onomastic palimpsest, representing accumulated iterations, glosses or etymologies laid one over the other, literally the accumulation and reinforcement of toponymic ideas over time. It is common to find place names with contested histories - a careful reading of any place names dictionary will reveal many examples. It is plausible that the dispute over possession of the beached whale predated and preempted the use of the site as a convincing ground in Tyers' sense, where the whalers elected to settle their own disputes, that is, that it became the ground where the whalers chose to settle disputes between themselves, as they had earlier with the Aborigines. Thus it is possible that both explanations are not mutually exclusive, and may both have integrity, yet Connor does not countenance this possibility.

\section{Origin of name: Mitchell's 1836 Australia Felix expedition}

In the third explanation which is posited by local Portland historian JG Wiltshire, ${ }^{75}$ and repeated by Wright, ${ }^{76}$ the name is held to have originated with Major Thomas Mitchell's Australia Felix 1836 exploration party, who, at that point on the coast on 30 August 1836, was convinced that 'the shapes which I thought were rocks were indeed whalers' huts' ${ }^{77}$ However, the major problem with this explanation is that the place name existed before Mitchell's visit. The earliest reference to the Convincing Ground locality is an entry in Edward Henty's diary dated 17 September 1835, where he noted that he 'walked to Convincing Ground' ${ }^{78}$ This reference proves that the explanation that the name originates from Mitchell is erroneous. I was one of the first to note the shortcomings of Wiltshire's explanation, yet it is still promulgated by some sources such as Wright. ${ }^{79}$

So we have three accounts of the origin of the 'Convincing Ground' toponym: Blair's account that it related to a particular conflict between Aboriginal people and whalers over a beached whale; Tyers' account that it originated from the settlement of disputes between whalers; and Wiltshire's version that it is connected with the explorer, Mitchell's, 1836 visit to Portland.

75 Wiltshire 1976.

76 Wright 2003.

77 Wiltshire 1976: 26.

78 Peel 1996: 89.

79 Clark 1990; Wright 2003: 39. 
In discussing the shortcomings of 'historical realism', ${ }^{80}$ Attwood has noted that the lack of hard documentation in academic accounts for an alleged killing 'does not necessarily mean that the violence that their accounts point towards did not occur. (A lack of hard evidence does not mean the absence of a violent event)' ${ }^{81}$ Attwood promotes another approach 'reading the signs' as offering new potential to understand the past. He writes:

As such, the task of the historian is not simply one of extracting information or quarrying facts from historical sources in order to reveal some reality. (Reading the signs regards this approach as necessary and crucial for historical research, but not as sufficient). Instead, the role of the historian is also one of discerning meaning in historical texts by attending to their creative dimension in order to suggest what the reality might have been. In this, historians contend that much in historical sources points to the real rather than reflecting it. ${ }^{82}$

Robinson was adept at reading the signs when he met both Aboriginal people and Europeans on the frontier. He read such contextual evidence as the fractured Aboriginal demography on the Portland coast, and the inter-cultural interaction he witnessed at Portland and its hinterland, especially the views he received from Henty, Blair, and Lilley, as supporting Blair's explanation of the origin of the Convincing Ground place name. All this points to this toponymic explanation as the most likely.

\section{Evidence for violence between Aboriginal people and whalers in Portland Bay}

Corris has noted that the 'sealers and whalers who began to visit the southwest coast early in the nineteenth century left little evidence of their activities there', and observed that evidence of their relations with Aborigines is hard to find. ${ }^{83}$ He observed that local squatter Thomas Browne aka Rolf Boldrewood 'hinted at more violent and passionate contacts between whalers such as "Port Fairy

80 Attwood (2005a: 161) understands this as the view of some historians 'that the frontier could be known by adopting conventional scientific methods', by assuming 'that historical truth would be realised by doing large amounts of research and sifting through the so-called historical record for historical facts (which they regarded as "hard historical evidence"). They asserted that their interpretations were grounded in the historical sources and historical facts, and they provided accounts in which they amassed examples and detail as documentary proof of the story they told'.

81 Attwood 2005a: 162. This latter point is worth reinforcing. Many early colonists such as Niel Black (Journal 9 December 1839), GT Lloyd (1862), and Henry Meyrick (correspondence 30 April 1846) confirm that violence against Aboriginal people and Aboriginal deaths were widespread in early Victoria. Meyrick's letter reveals an unwillingness to detail this violence and suggests that there existed in colonial Victoria an attitude of silence that preserved the anonymity of those involved and made detection extremely difficult. Connor fails to discuss this silence.

82 Attwood 2005a: 163.

83 Corris 1968: 52. 
Campbell and his merry men", and the Aborigines, but he gave no details' ${ }^{84}$ In March 1836, John Wedge in a letter to John Montagu, the Colonial Secretary of Van Diemen's Land, referred to an attack on Aboriginal people in Westernport Bay by a party of whalers who were employed to strip bark. Captain Hart brought Charles Griffiths' party of whalers from Portland at the end of the 1834 season to Western Port to strip wattle-bark in an effort to keep them in employment and prevent them from being employed by an opposition fishing party. ${ }^{85}$ Wedge discussed attacks on Aborigines at Portland, in the following words:

About a year and a half ago a similar attack was made upon the natives and four of their women were taken from them. It is to be lamented like outrages have been committed upon the Aborigines at Portland Bay and other whaling stations, and unless some measures be adopted to protect the natives, a spirit of hostility will be created against the whites, which in all probability will lead to a state of warfare between them and the Aborigines, which will only terminate when the black man will cease to exist. ${ }^{86}$

In 1839, a Launceston doctor, GC Collier wrote to the Colonial Secretary in Sydney of an alleged massacre of Aboriginal people in Portland Bay by exconvict servants of the Henty family. Governor Gipps directed Police Magistrate Captain Foster Fyans to investigate the allegations. Of the men at Portland, Henty reported 'from the appearance of the men about the place, I conclude they are a bad lot of ruffians ${ }^{87}$ - quite independent ... every fellow appears the Master and no doubt numerous bad, and improper acts, have been committed and hid from $\mathrm{us}^{\prime}{ }^{88}$ Fyans recommended that a Police Magistrate and three constables and three mounted policemen be appointed 'which would be the means of ... keeping the community in decent order for if allowed to go on in their present state - I fear all will not end well' ${ }^{89}$ Fyans noted of the Aborigines in the Portland district in 1839: 'About 30 miles from this [Portland] towards Port Fairy, the natives are numerous and to all appearance in great agitation on our appearance, which to me fully proves of bad acts being committed on them' ${ }^{90}$ Police Magistrate James Blair once he had taken his position at Portland 'certainly found the men unruly. He described the Portland population as composed of the "very dregs of society". "The majority of the people here", he wrote in late 1840, "are men who had absconded from whaling gangs and the lawless lives they have led ... render a much stronger force necessary to subdue them"'.$^{91}$

In all the correspondence from Collier, Fyans' report, and in the depositions taken from the Henty brothers, there is no reference made to the Convincing Ground.

84 Corris 1968: 52.

85 Powling 1980: 14.

86 JH Wedge to John Montagu, 15 March 1836 in Jones 1981: 35.

87 Jones (1981: 252) transcribes this as 'they are a sad set of ruffians'.

88 Bassett 1954: 446.

89 Bassett 1954: 446.

90 Jones 1981: 254.

91 Critchett 1990: 120-121. 
Edward Henty deposed that since his arrival on 19 November 1834, until October 1838 , 'we were on the most friendly terms with the natives' ${ }^{92}$ Stephen Henty gave Fyans the 'Journal of everything which has taken place at this establishment since November 1834, and to the best of my belief, every occurrence which has taken place has been entered in the books now produced and delivered to you' ${ }^{93}$ Stephen Henty, in his 1854 letter to La Trobe does not mention the Convincing Ground, but he does assert that during 1835, 'we were entirely dependent upon ourselves, both for supplies from Van Diemen's Land and for protection against the natives and the many runaway prisoners who were at large at and around the whaling establishment' ${ }^{94}$ The implications here are that the Hentys and their men were not involved in the Convincing Ground incident and/or that it occurred before they arrived in November 1834. Learmonth has observed that it 'was not until after two months' residence that any natives appear to have been seen near Henty's settlement; the sealers and whalers of former years had no doubt driven the aborigines back from the locality' ${ }^{\prime 95}$

\section{Who was involved?}

It is likely that the whalers who disputed ownership of the beached whale were 'tonguers'. Tonguers 'were those who contracted to tow the whale carcasses ashore and to cut them up and who received in payment the oil from the dissected carcass, including the tongue and interior parts' ${ }^{96}$ The violence levelled at Edward Henty by his whaling men during a dispute over pay in April 1835, when Henty intimated he was going to cut a beached whale with help from other employees, adds credibility to the massacre account. ${ }^{97}$ If the whalers were willing to threaten Henty with violence, how much more violent would they have been willing to be toward Aboriginal people over possession of a disputed whale?

In terms of the Aboriginal people involved, it is presumed that those involved were local clanspeople - three clans in Portland and its surrounds have been reconstructed: the Kilkarer gundidj of the Convincing Ground and the Ngure gundidj and Borne gundidj from the vicinity of Portland. ${ }^{98}$ In 1841 Robinson learned that the Kilkarer gundidj clan that belonged to the Convincing Ground had been reduced to two young men: Pollikeunnuc and Yarereryarerer. He

92 Cannon 1983: 631.

93 Cannon 1983: 633.

94 Bride 1983: 123f.

95 Learmonth 1934: 103. In the 1845 Report from the NSW Select Committee on the Condition of the Aborigines, James Malcolm, a settler at Merriang, north of Melbourne, since 1836 (see Billis and Kenyon 1974: 110), replied to the question 'to what extent the blacks have suffered loss of life from the whites?', that 'I have heard that some blacks have been killed in the district; but this has not been the case with us, so much as it is said to have been in the Portland Bay District' (New South Wales 1845: 15).

96 Bassett 1954: 310.

97 Peel 1996: 61.

98 Clark 1990. 
also noted that the remnant of these clans had united with the Kart gundidj of Mount Clay, where they remained. ${ }^{99}$ The western end of the Mount Clay range is within 13 kilometres of Portland. ${ }^{100}$ This demographic information is consistent with the Aboriginal origin of the Convincing Ground name and attests to some intervention in their decline. It is also consistent with Wedge's correspondence that 'outrages have been committed upon the Aborigines at Portland Bay and other whaling stations'. ${ }^{101}$ It underscores that introduced disease can not plausibly account for this demographic decline, as it is unlikely that three contiguous coastal groups would be practically defunct by 1841, yet an inland group only 13 kilometres away would be some 158 strong. This demographic contrast was noted by Wiltshire when he observed that by the 1830s there were very few Aboriginal people belonging to Portland remaining, however not far inland, 'there were quite a number of natives living their normal lives' ${ }^{102}$

Robinson also learned that Aboriginal people had not visited the Portland township since its formation. The entries in Robinson's journal and report are as follows:

[Edward Henty] Said the blacks had not visited the settlement at the bay for some years and the blacks at Mount Clay and between the first and second rivers are a wild set and will not allow white persons to come to them. (In this they are wise). ${ }^{103}$

There have been no natives seen at Portland for the [blank] years. Indeed, they never visit the town and the Mount Clay natives will not allow any person to go near them. ${ }^{104}$

[George Lilley, merchant, auctioneer and commission agent] said a black had not been seen in the town for some years. He thought all was not right. ${ }^{105}$

No natives were seen in the township or vicinage since its formation and the nearest were those of Mount Clay, twenty miles east but too wild it was said to communicate with. ${ }^{106}$

This is a significant point for in other settlements in the Port Phillip district, such as Melbourne and Geelong, Aboriginal presence was a major issue and protectorate officials were under constant pressure from colonial authorities to discourage Aboriginal people in townships. ${ }^{107}$ The extraordinary absence of Aboriginal people from the Portland township and the existence of a remnant

\footnotetext{
99 Robinson, Journal 19-20 May 1841 in Clark 2000a.

100 Bonwick 1970: 91.

101 Wedge's 1836 in Jones 1981: 35.

102 Wiltshire 1975: 10.

103 Robinson, Journal 15 May 1841 in Clark 2000a: 202.

104 Robinson, Journal 16 May 1841 in Clark 2000a: 206.

105 Robinson, Journal 21 May 1841 in Clark 2000a: 217.

106 Robinson 1842 report in Clark 2001: 21.

107 Cannon 1993: 66f.
} 
from the three clans local to Portland also supports the thesis that relations between the whalers and local Aboriginal people at Portland were poor. ${ }^{108}$ Another observation that requires some explanation is that until Robinson's visit in 1841, Aboriginal people had kept away from the whaling stations in Portland Bay. This is contrary to the situation in South Australia where whaling stations attracted large numbers of Aboriginal people. ${ }^{109}$ Aboriginal avoidance of Portland and its whale fisheries attests to a violent past, and supports the likelihood that a massacre took place.

\section{How many Aboriginal people were killed?}

In terms of the Convincing Ground incident and the number of Aboriginal deaths, Robinson noted the following in his journal:

My acquaintence with the natives is not so intimate as to ascertain the extent of the injuries to which they have been subjected but it has not been of the best description as the admission of E. Henty and others of the attack made in consequence of the whale will shew. There is only two of the tribe who once inhabited the country at the Convincing Ground now alive (see vocabulary), and only one old man who belonged to the tribe once belonging to the country where the township of Portland now is. ${ }^{110}$

In his official report of his 1841 journey, Robinson reported that 'a large number of the former [ie Aborigines] were slain'. ${ }^{111}$

Connor is right to be concerned with the estimates of the death toll of the massacre. Some of them are extrapolations based on estimates of typical Aboriginal clan sizes in south-west Victoria. However there are potentially so many depopulation variables at play (such as European violence, introduced disease, infertility caused by venereal disease) that any death count for this massacre can only be speculative. The most explicit comment from Robinson was that a large number of Aborigines were slain. This is supported by the depopulation he noted of the three clans in the immediate neighbourhood of the Convincing Ground locality.

Robinson made the following entries concerning the specific demography of the Kilkarer gundidj belonging to the Convincing Ground locality:

108 Connor (2005a: 144) asserts that I have 'misrepresented' these entries. I agree with Conner that my assertions that there was a Kart gundidj embargo on visits to the township (see Clark 1990: 33; 1995: 22) is a misreading of 'will not allow any person to go near them'. However, Connor's interpretation of the significance of the absence of Aboriginal people in Portland since its formation is similarly flawed. There are four distinct references to this avoidance and Connor (2005: 144) only alludes to the first two. Arkley's (2000: 177) reading of these texts is consistent with my reading, that is, that Aboriginal people had been absent from Portland for several years.

109 See Clarke 2001: 29.

110 Robinson, Journal in Clark 2000a: 216.

111 Clark 2001: 21. 
Yare.rer.yare.rer.mer.nite, 18, and Pol.like.un.nuc, 18, the wild young man who was troublesome to me, are Kil.care.rer conedeet, country between Surrey and Double Corner. These two are all that are left of that tribe, so they stated. ${ }^{112}$

There is only two of the tribe who once inhabited the country at the Convincing Ground now alive (see vocabulary), and only one old man who belonged to the tribe once belonging to the country where the township of Portland now is. ${ }^{113}$

In his papers of vocabulary notes and jottings that he took while in the field, Robinson lists six Kilkarer conedeet:

- Yam.bur.rer

- Pone.gare.rer.min

- Pol.like.en.nuc

- Pone.gare.rer.min

- Car.cur.rer.cort

- Um.ber.rer.boorn. ${ }^{114}$

However there are inconsistencies between this and a list of 'Cart conedeet', where at least three of these names are recorded as 'Cart conedeet': 1. Yarm. bar.rer; 2. Poeng.gar.rer.min; 3. Poenk.ar.rer.min. ${ }^{115}$ Assuming Robinson's larger Kilkarer gundidj list is in error, this leaves four Kilkarer gundidj, the two young men Yarereryarerermite and Polikeunnuc and another two: Carcurrercort and Umberrerboorn. It is possible that Robinson's field notes were wrong and he corrected them when he wrote his journal entries. However, it is important to note that when he wrote his official report of his 1841 journey he did not amend his journal observation that there were only two Kilkarer gundidj men living. In his official report of the 1841 journey, Robinson presented the following: 'of the once powerful Kil-care-er, who inhabited the country between Portland and the Surry River, two young men, Pol-like-un-nuc and Yare-rer-yare-rer, survive'.

Writing on Kilkarer gundidj demography, Critchett notes that there were six Kilcarer 'survivors' near Portland in $1841 .{ }^{116}$ Connnor is also aware of the larger figure in Robinson's papers and asserts: 'Although this [the claim that there are only two left of this group] has been generally accepted by historians it is incorrect' ${ }^{117}$ Clearly Critchett and Connor did not examine the various census lists with any care, for had they done so they would have been aware of the discrepancies identified above. Connor makes much of the different estimates

112 Robinson, Journal 19 May 1841 in Clark 2000a: 213.

113 Robinson, Journal 20 May 1841 in Clark 2000a: 216.

114 Clark 2000b: 111.

115 Robinson papers Clark 2000b: 112.

116 Critchett 1990: 78.

117 Connnor 2005a: 145. 
of the death toll, yet given the careful analysis of the demographic information available to us, we will never know the precise numbers of Aboriginal people killed in this massacre. This is the case with most mass killings.

\section{When did the massacre occur?}

In my reconstructions I have considered that the massacre took place in 183334. ${ }^{118}$ Critchett concurs with this timeframe. ${ }^{119}$ There are four references in Robinson's writings that mention when the event may have taken place:

- 'two or three years ago'. ${ }^{120}$ Robinson is guessing here, and if the incident is the source of the place name, then his guess is obviously incorrect, as primary sources show the name was in common usage in 1835, which is something Robinson would not have been privileged to know as he was not a local.

- 'It was the first year of the fishery, and the whalers having used their guns beat them off and hence called the spot the Convincing Ground' ${ }^{121}$ If the origin of the place name is tied to the conflict over a beached whale, and as the name was in usage by 27 October 1835, then it had to be before October 1835.

- 'It was 8 or 9 years ago the collision between the whalers \& blacks took place at the Convincing Ground'. ${ }^{122}$ The source of this statement is unclear. It could be the whaler Captain Alexander Campbell, or MacDonald, a headsman, presumably in the employ of Campbell, or an unidentified Aboriginal source.

- 'severe conflict which took place a few years previous'. ${ }^{123}$

In 1841 Robinson was told by Henty and Blair that the event occurred in the first year of the fishery at Double Corner. However, given Wedge's October 1835 account that there were three whaling establishments at Double Corner, it is unclear as to which fishery Robinson is alluding to. The Henty brothers established their fishery during the 1835 whaling season, ${ }^{124}$ and although this is the year in which Edward Henty first began to use the place name, later correspondence between the Henty brothers and colonial authorities never mentioned the Convincing Ground in any discussion of conflict with Aboriginal people. Therefore, the year 1835 is unlikely as there is no reference to the confrontation in any of the writings of the Henty brothers for that year. Presumably, then it occurred prior to Edward Henty's arrival in November 1834, which means that the reference to the first year of the fishery, must be

118 Clark 1989: 16; 1990: 63; 1995.

119 Critchett 1990: 121-122.

120 Robinson, Journal 16 May 1841 in Clark 2000a: 205.

121 Robinson, Journal 17 May 1841 in Clark 2000a: 208.

122 Robinson, Journal 23 March 1842 in Clark 2000a vol 2: 48.

123 Robinson 1841 Report in Clark 2001: 21.

124 Peel 1996. 
to another fishery, presumably William Dutton's. The third reference dates the massacre occurring in either 1833 or 1834, and this temporal reference is the most plausible, as this period falls within the first year of Dutton's fishery from March 1833 to March $1834,{ }^{125}$ thus there is a synchronicity between Robinson's second and third references.

Connor asserts that one of the fundamental problems with the dating of the Convincing Ground incident as being in the whaling season of 1833/34 is that 'Clark undermines his own case. For at that time, Edward Henty, whose story is our only source for the incident, had not even arrived at Portland'. ${ }^{126}$ Yet it is curious that Connor does not apply this same concern to Tyers or Dunderdale, neither of whom were present at the genesis of the Convincing Ground toponym. He is happy to accept them as sources, even though Tyers had not arrived until late 1840 and Dunderdale had not arrived in Victoria until 1853.

\section{Conclusion}

In 2005, Connor presented a case study in which he assessed the historiography of the Convincing Ground. He concluded: 'On the presently available evidence there probably was a fight between Aborigines and whalers over a carcass of a whale at Portland but it was probably not at Convincing Ground and probably Convincing Ground was not named because of a massacre. A possibility is that the whale in Henty's story broke free and ended up beached at or near Double Corner, not at the Convincing Ground, and the fight took place there' ${ }^{127}$ According to Anderson, by focussing 'on anomalies in dates, transcription errors ${ }^{128}$ and descriptions of events by various people as recorded by George Augustus Robinson and subsequently analysed by academic historian Ian Clark', Connor 'seeks to support his broader agenda that academic historians have manipulated sources to present incorrect evidence, and bad history' ${ }^{129}$ Anderson's assessment of Connor's critique of the historiography of the Convincing Ground is that 'on the balance of "probabilities" Connor fails to achieve his goal of undermining Robinson's credibility as the sole official source and Clark's subsequent analysis, though he does raise legitimate concerns about the work of later researchers and cultural heritage consultants, who have arrived at their own conclusions with no basis in the historical facts available' ${ }^{130}$ Anderson further comments

125 Wiltshire 1975: 16.

126 Connor 2005a: 149.

127 Connor 2005a: 133-134.

128 It is interesting to note that when the Heritage Council of Victoria registered the Convincing Ground on the Victorian Heritage Register, it commented: 'The submissions to the Committee contain numerous discussions about the differences in transcription of Robinson's journals. ... The Committee has reviewed these, and concludes that given the difficult nature of the original documents, transcription errors are unsurprising, and that most of the possible differences in transcriptions raised at the Hearing are of little consequence in determining the cultural heritage significance of this place' (Buckley et al 2006: 13 in Anderson 2006: 139).

129 Anderson 2006: 139.

130 Anderson 2006: 139. 
that Connor's claim that the 'good news is that the [massacre] probably never happened' is 'sensationalised' and 'unsupported' by Connor's own research. ${ }^{131}$ Warden has noted that '[o]ne of the more instructive outcomes of the history wars has been the reminder, painful for some, that getting one's facts and footnotes right is a duty rather than a virtue.... The recent battle of the facts and the footnotes has inflated and exaggerated simple errors into gross moral failing. What was once pedantry in criticism has been newly fashioned as a flail against the fabricators' ${ }^{132}$

This study has shown that Connor's research into the usage of the phrase 'convincing ground' in the nineteenth century has been superficial. Likewise, his analysis of publications that discuss the specific Convincing Ground toponym near Portland has been inadequate. He failed to refer to Dunderdale's first edition and was unaware of Moorhouse's Manchester address. Although Connor has attempted to deny that the Convincing Ground massacre took place, his tactics of massacre denial have failed. He has employed methods of exegesis and report discounting to dismiss evidence that does not suit his argument; he has used the tactic of deflection; deliberately obfuscated the evidence; contested the integrity of the informants and the situation in which the evidence was first presented; challenged the integrity of GA Robinson; questioned the different estimates of the death toll; and focused on minor anomalies in dates and mistranscriptions as evidence of 'bad history'. The actual date of the massacre is uncertain, and we may never know the numbers of Aboriginal people killed. However the evidence that it took place is overwhelming.

Connor's wider research also has been found wanting. His preference for one explanation of the origin of the Convincing Ground toponym over the other is biased and his examination of other uses of the term 'convincing ground' is superficial and inadequate. His analysis suggests his position was predetermined. He avoided consideration of the implications of three factors: the demographic decline of the Aboriginal clans in the vicinity of Portland; Aboriginal avoidance of Portland; and independent confirmation that relations between the whalers and Aboriginal people at Portland Bay were violent. When taken together these factors support the narrative that the Convincing Ground toponym has its origin in a dispute between whalers and Aborigines over a beached whale. Furthermore, Connor fails to consider the possibility that the phrase 'convincing ground' is polysemous which means that we should not expect to find a singular homogenous explanation or application in the literature. He also fails to discuss the real possiblity that the toponym may be a palimpsest and that both the Aboriginal-whaler dispute narrative and the intra-whaler dispute narrative may be legitimate explanations relevant at particular moments in the place's history.

131 Anderson 2006: 141.

132 Warden 2006: 6 (itals in original). 
ABORIGINAL HISTORY 2011 VOL 35

\section{References}

\section{Unpublished sources}

VPRS 10/P Inward Registered Correspondence to the Superintendent of Port Phillip District, relating to Aboriginal Affairs, unit 3, item 41/830.

Black, N Journal 30 September 1839 to May 1840, La Trobe Library, State Library of Victoria, Melbourne, 79 pp, typescript copy of original, Ms 1159.

Connor, M 2006, 'Submission in Reply prepared by Dr Michael Connor for Mr Michael Maher', Unpublished paper.

Meyrick, HH, Letters 1840-47, La Trobe Library, State Library of Victoria, Melbourne, H 15789-15816.

Parker, G 2005, 'The "Convincing Ground", Portland Bay: the unlikely site of an 1830's massacre of Aborigines by European whalers', Unpublished manuscript, 9pp, Convincing Ground Files, Portland History House, Portland.

\section{Newspapers}

The Argus

The Courier [Brisbane]

The Courier [Hobart]

Hobarton Mercury

The Mercury

Portland Guardian

Sydney Morning Herald

\section{Published sources}

Anderson, R 2006, 'The Convincing Ground: a case study in frontier and modern conflict', Bulletin of the Australasian Institute for Maritime Archaeology 30: 137147.

Anonymous 2004, The Convict Ship 'Success': The Last 'floating hell', Digital Antiquaria, Morristown, NJ, USA. 
Arkley, L 2000, The Hated Protector: The story of Charles Wightman Sievwright, Protector of Aborigines 1839-1842, Orbit Press, Mentone, Victoria.

Attwood, B 2005a, Telling the Truth about Aboriginal History, Allen \& Unwin, Crows Nest, New South Wales.

- 2005b, 'Telling the truth about Aboriginal History', 2005 Annual Public Lecture - Institute for Public History, Monash University, accessed 14 May 2010: <http://arts.monash.edu.au/public-history-institute/annual-publiclecture/lecture-2005/index.php>

Badger, CR 1974, 'Moorhouse, James (1825-1915)', Australian Dictionary of Biography, vol 5, Melbourne University Press, Melbourne: 281-283.

Bassett, M 1954, The Hentys: an Australian Colonial Tapestry, Oxford University Press, Melbourne.

Billis, RV and AS Kenyon 1974, Pastoral Pioneers of Port Phillip, Stockland Press Pty Ltd, North Melbourne, Victoria.

Boldrewood, R [Browne, TA] 1969, Old Melbourne Memories, William Heinemann, Melbourne.

Bonwick, J 1970, Western Victoria Its Geography Geology and Social Condition the Narrative of an Educational Tour in 1857, William Heinemann Australia, Melbourne.

Bradmore, K 2005, 'Historian defends claim of Victoria's first Aboriginal massacre near Portland', ABC South West Victoria Breakfast program, 11 October 2005, transcript, accessed 26 May 2010:

<http:/ / abc.com.au/local/stories/2005/10/11/1479719.htm>

Bride, TF (ed) 1983, Letters from Victorian Pioneers, Currey O'Neil, South Yarra.

Buckley, K, S Brennan and D Cash 2006, 'Convincing Ground, Allestree, Heritage Council Registrations Committee, Explanatory Notes', 3 April, Heritage Council of Victoria, Melbourne.

Cannon, M (ed) 1983, Aborigines and Protectors 1838-1839, Historical Records of Victoria, Vol. 2B, Victorian Government Printing Office, Melbourne.

Cannon, M1993, Black Land, White Land, Minerva Press, Port Melbourne, Victoria.

Clark, ID 1988, The Port Phillip Journals of George Augustus Robinson: 8 March - 7 April 1842 and 18 March -29 April 1843, Monash Publications in Geography, No 34, Clayton. 
- 1989a, 'Squatters' journals', The La Trobe Journal 43: 16-18.

- 1989b, 'The Killing Fields of the Western Plains: significant Aboriginal massacre sites in Western Victoria', Unpublished report to the Victorian Tourism Commission, July.

- 1989c, "“How the west was won": six significant massacre sites in Western Victoria', Unpublished report to the Victorian Tourism Commission, December.

- 1990a, Aboriginal Languages and Clans: An Historical Atlas of Western and Central Victoria 1800-1900, Monash Publications in Geography, No 37, Clayton.

- 1990b 'In quest of the tribes: G.A. Robinson's unabridged report of his 1841 expedition among Western Victorian Aboriginal tribes: Kenyon's "condensation" reconsidered', Memoirs of the Museum of Victoria Anthropology and History 1(1) : 97-130.

- 1994, 'Convincing Ground Massacre', in Encyclopaedia of Aboriginal Australia, vol 1, D Horton (ed), Aboriginal Studies Press, Canberra: 223.

- 1995, Scars in the Landscape, a Register of Massacre Sites in Western Victoria, 1803-1859, Aboriginal Studies Press, Canberra.

- 1998, The Journals of George Augustus Robinson, Chief Protector, Port Aboriginal Protectorate, Vols. 1-4 1839-1845, Heritage Matters, Melbourne.

- 2000a, The Journals of George Augustus Robinson, Chief Protector, Port Aboriginal Protectorate, Vols. 1-6 1839-1852, Heritage Matters, Clarendon.

- 2000b, The Papers of George Augustus Robinson, Chief Protector, Port Phillip Aboriginal Protectorate, Vol. 2 Aboriginal Vocabularies 1839-1852, Heritage Matters, Clarendon.

- 2001, The Papers of George Augustus Robinson, Chief Protector, Port Phillip Aboriginal Protectorate, Vol. 4 Annual and Occasional Reports 1841-1849, Heritage Matters, Clarendon.

Clark, ID and EJ Ryan 2005, 'The Convincing Ground Massacre Site, Portland Bay: an ethno-historical assessment prepared for Aboriginal Affairs Victoria', Unpublished Report, School of Business, University of Ballarat.

Clarke, PA 2001, 'The significance of whales to the Aboriginal people of southern South Australia', Records of the South Australian Museum 34(1): 19-35.

Connor, M 2005a, The Invention of Terra Nullius, Macleay Press, Sydney.

- 2005b, 'The Australian massacre that wasn't', The Australian, 9 March 2005. 
- 2007, 'Convincing Ground: an invented massacre', Quadrant Online, 1 December 2007, accessed 14 May 2010: <http://www.quadrant.org.au/ blogs/history-wars/2007/12/convincing-ground-a-history>

- 2010, 'History on fire', Quadrant LIV(4): 32-36.

Corris, P 1968, Aborigines and Europeans in Western Victoria, Occasional Papers in Aboriginal Studies No 12, Ethnohistory Series No 1, Australian Institute of Aboriginal Studies, Canberra.

Critchett, JF 1990, A Distant Field of Murder Western District Frontiers 1834-1848, Melbourne University Press, Melbourne.

Dunderdale, G 1973[1870], The Book of the Bush, Penguin, Ringwood [Ward, Lock and Co. Ltd, London].

England, GE no date, 'Local Place Names', Coffs Harbour City Library, Coffs Harbour, accessed 14 May 2010: <http:/ / libraries.coffsharbour.nsw.gov.au/ Local-Heritage/collection/Pages/local-place-names.aspx>

Evans, R 2007, A History of Queensland, Cambridge University Press, Port Melbourne.

Garryowen (E Finn) 1888, The Chronicles of Early Melbourne 1835 to 1852. Historical, Anecdotal and Personal ..., 3 vols, Fergusson \& Mitchell, Melbourne.

Hodges, F 2007, 'Language planning and placenaming in Australia', Current Issues in Language Planning 8(3): 383-403.

Jones, P (ed) 1981, Beginnings of Permanent Government, Historical Records of Victoria, Vol. 1, Victorian Government Printing Office, Melbourne.

Kenyon, AS 1928, 'The Aboriginal Protectorate of Port Phillip. Report of an Expedition to the Aboriginal Tribes of the Western Interior by the Chief Protector, George Augustus Robinson', Victorian Historical Magazine 12: 134171.

Kirby, J 1895, Old Times in the Bush of Australia Trials and Experiences of Early Bush Life in Victoria, During the Forties, Geo. Robertson \& Co., Melbourne.

Learmonth, NF 1934, The Portland Bay Settlement Being the History of Portland, Victoria from 1800 - 1851, The Historical Committee of Portland, Portland.

- 1970, Four Towns and a Survey, The Hawthorn Press, Melbourne.

Lloyd, GT 1862, Thirty-three Years in Tasmania and Victoria, Houlston and Wright, London. 
McFarlane, I 2008, 'NJB Plomley's contribution to North-West Tasmanian regional history', in Reading Robinson: Companion Esssays to Friendly Mission, A Johnston and M Rolls (eds), Quintus Publishing, Hobart: 127-142.

MacKenzie, JM 1976, Sealing, Sailing and Settling in South-western Victoria, Lowden Publishing, Kilmore.

Mann, W 1839, Six Years' Residence in the Australian Provinces Ending in 1839, Smith, Elder, \& Co, London.

Michie, F 2005, 'The site where Aboriginal history is clashing with commercial development', ABC Stateline Victoria, 21 October 2005, accessed 2 June 2010: <http:/ / www.abc.net.au/stateline/vic/content/2005/s1487903.htm>

Mitchell, TL 1996, Three Expeditions Into the Interior of Eastern Australia ..., Eagle Press, Maryborough.

Moorhouse, J 1888, 'Victoria', The Journal of the Manchester Geographical Society IV: 38-57, map [Published in June 1889].

New South Wales 1845, Votes and Proceedings of the Legislative Council, Report from the Select Committee on the Condition of the Aborigines, W.W. Davies, Sydney: 59.

Partridge E and P Beale 2002, A Dictionary of Slang and Unconventional English, Eighth edition, Routledge, London.

Peel, L (ed) 1996, The Henty Journals..., Miegunyah Press, Melbourne.

Powling, JW 1980, Port Fairy: The First Fifty Years 1837-1887: A Social History, William Heinemann, Melbourne.

Presland, G (ed) 1980, Journals of George Augustus Robinson May - August 1841, Records of the Victorian Archaeological Survey, No 11, Melbourne.

Rickards, EC 1920, Bishop Moorhouse of Melbourne and Manchester, John Murray, London.

Semelin, J 2007, Purify and Destroy: The Political Uses of Massacre and Genocide, Translated from the French by Cynthia Schoch, Columbia University Press, New York.

Serle, P 1949, 'James Moorhouse (1826-1915)', Dictionary of Australian Biography, Angus \& Robertson, Sydney.

Staniforth, M 2008, 'European-Indigenous contact on shore-based whaling sites', in Strangers on the Shore Early Coastal Contacts in Australia, P Veth, P Sutton and M Neale (eds), National Museum of Australia, Canberra: 124-132. 
Sturrock, M 2005, Bishop of Magnetic Power: James Moorhouse in Melbourne, 18761886, Australian Scholarly Publishing, Melbourne.

Walsh, K and J Hooton 1998, Australian Autobiographical Narratives: An Annotated Bibliography Vol. 2: 1850-1900, Australian Scholarly Editions Centre, School of English, University of New South Wales, Australian Defence Force Academy, Canberra, and National Library of Australia, Canberra.

Warden, J 2006, 'Atramentous History', History Australia 3(2): 49.1-49.8.

Watt, J 2007, 'Dispute over Convincing Ground massacre site settled with a secret deal', ABC South West Victoria, online, 5 February 2007, accessed 26 May 2010: <http:/ / www.abc.net.au/local/stories/2007/02/05/1837204.htm>

Wheelwright, HW 1861, Bush Wanderings of a Naturalist; or, Notes on the Field Sports and Fauna of Australia Felix by an Old Bushman, Routledge, Warne, \& Routledge, New York.

Wiltshire, JG 1975, A People's History of Portland and District - Section One - The Aborigines, E. Davis, Portland.

- 1976, A People's History of Portland and District - Section Two - William Dutton and the Sealing and Whaling Industries, E. Davis \& Sons, Portland.

Wright, T 2003, Turn Right at Istanbul: A Walk on the Gallipoli Peninsula, Allen \& Unwin, Crows Nest, New South Wales. 